\title{
Treatment of superficial basal cell carcinoma with ingenol mebutate gel, $0.05 \%$
}

\author{
Miriam S Bettencourt ${ }^{1,2}$ \\ 'Advanced Dermatology and \\ Cosmetic Surgery, Henderson, \\ 2Department of Dermatology, \\ University of Nevada, \\ Las Vegas, NV, USA
}

This article was published in the following Dove Press journal:

Clinical, Cosmetic and Investigational Dermatology

16 August 2016

Number of times this article has been viewed

Background: Basal cell carcinoma (BCC) is the most common cancer in Caucasians. Surgical approaches are the most widely used and effective treatment strategies for well-defined BCC. However, for patients with low-risk, superficial BCCs (sBCCs), medical therapy may be a treatment option. In this small case series, we describe our experience in using topical treatment with ingenol mebutate gel, $0.05 \%$, for patients who refused surgical treatment for $\mathrm{sBCC}$. Methods: We conducted a retrospective chart review of seven patients from our community dermatology practice for whom SBCC was treated with ingenol mebutate. The chart review extracted information on demography, dermatologic history, and prior treatment for actinic keratosis or skin cancer. Summary of the treatment outcome with ingenol mebutate included the size and location of the sBCCs, description of administration, local skin reactions, adverse events, and efficacy.

Results: Histopathologic analysis of a shave biopsy sample of suspicious lesions on the trunk confirmed nine sBCCs: a single sBCC in five patients and two well-separated lesions in each of the other two patients. Patients were treated at 10 to 14 days after shave biopsy; biopsy sites were not required to be fully healed. Lesions were either occluded using a standard adhesive bandage ( $n=6)$ or not occluded $(n=3)$. All patients experienced local skin reactions that began on day 1 or 2 of treatment, peaked on days 2 to 7 , and were largely resolved at 2 weeks. All sBCCs were clinically resolved on short-term follow-up at 2 to 4 weeks. Repeat biopsy of six lesion sites in four patients at 3 or 4 months confirmed histologic clearance. There were no clinically suspicious lesions in any patients at subsequent follow-up evaluations at 3-month intervals. The longest follow-up to date has been 14 months.

Conclusion: Ingenol mebutate gel, $0.05 \%$, was efficacious and well tolerated for the treatment of biopsy-confirmed sBCCs on the trunk in seven patients.

Keywords: superficial basal cell carcinoma, ingenol mebutate, nonsurgical treatment, local skin reaction

\section{Introduction}

Basal cell carcinoma (BCC) is the most common cancer in Caucasians and is the leading cancer in the United States. ${ }^{1}$ Its exact incidence is difficult to determine because it is not reported to national registries. ${ }^{2,3}$ However, analysis of US government claims databases for nonmelanoma skin cancer (NMSC), which includes BCC and squamous cell carcinoma, demonstrates dramatic increases in the total number of procedures for NMSCs and in the number of persons treated since 2002., ${ }^{2,3}$ Prospective cohort studies have also confirmed a steady increase in the age-adjusted rates of BCC in both males and females. ${ }^{4}$ Although NMSC generally occurs in people over 50 years of age, significant
Correspondence: Miriam S Bettencourt Advanced Dermatology and Cosmetic Surgery, I70I N Green Valley Pkwy Suite 7B, Henderson, NV 89074, USA

$\mathrm{Tel}+\mathrm{I} 7022577546$

Fax +I 7028704824

Email drmiriam@cox.net 
increases in BCC have been noted in young people under the age of 40, particularly females, ${ }^{5}$ in whom the use of indoor tanning devices has been implicated. ${ }^{6}$ BCCs are commonly slow-growing tumors that rarely metastasize. Nonetheless, they can be locally invasive and result in considerable cosmetic, functional, and economic burdens. ${ }^{1,7}$

Surgical excision with predetermined margins is one of the most widely used and effective treatment strategies for well-defined BCCs; Mohs micrographic surgery is generally applied to higher-risk tumors and those in cosmetically sensitive areas. ${ }^{7,8}$ For superficial BCCs (sBCCs) of small size on the trunk or limbs, electrodessication and curettage (EDC) is an acceptable option of treatment..$^{7-10}$

For those sBCCs deemed to be at low risk for recurrence, medical therapy with topical treatments or photodynamic therapy is a treatment option in appropriately selected patients. ${ }^{710}$ Some patients may be poor candidates for surgery, and others may prefer nonsurgical and nondestructive methods of treatment to reduce the risk of scarring. ${ }^{8}$ Although surgical methods remain the gold standard, medical modalities are valid, nonsurgical treatment options when appropriate..$^{7,10}$

Ingenol mebutate gel, $0.05 \%$, applied once daily for 2 consecutive days, is approved for the treatment of actinic keratosis in affected areas of $25 \mathrm{~cm}^{2}$ on the trunk and extremities. ${ }^{11}$ Ingenol mebutate gel is not indicated for treatment of sBCC; however, its safety and efficacy for treating histologically confirmed $\mathrm{sBCC}$ were reported from a Phase IIa study, evaluating two applications of ingenol mebutate at concentrations of up to $0.05 \%$ in a small number of patients. ${ }^{12}$ In the treatment arm in which patients received the $0.05 \%$ strength administered for 2 consecutive days, five of the eight patients $(63 \%)$ achieved histologic clearance at day 85 , as compared with none of the five patients in the vehicle group $(P<0.031) .^{12}$

The small case series presented here describes our experience in using ingenol mebutate gel, $0.05 \%$, for $\mathrm{sBCC}$ in patients who refused surgical treatment.

\section{Methods}

We conducted a retrospective chart review of seven patients from our community dermatology practice for whom sBCC was treated with ingenol mebutate gel, $0.05 \%$. The chart review extracted information on demography, patient's dermatologic history, and prior treatment for actinic keratosis or skin cancer. Analysis of the treatment outcome with ingenol mebutate included the size and location of the sBCCs, description of administration, clinical assessment of local skin reactions (LSRs), adverse events, efficacy, and results of follow-up from clinic visits at 3-month intervals. All patients provided informed consent verbally for treatment and participation in this study. Ethical approval was not sought since the study did not take place in a hospital or academic setting and because this was a retrospective chart review study.

\section{Results \\ Description of patients}

The seven patients (three men, four women; age range 47 to 75 years) presented with primary lesions that were suspicious for BCC (Table 1). Histopathologic analysis of a shave biopsy sample confirmed nine low-risk sBCCs: a single sBCC in each of five patients and two well-separated lesions in each of two patients. All lesions occurred on the trunk and were located on the back $(n=5)$, chest $(n=2)$, or shoulder $(n=2)$. Lesion size ranged from 0.6 to $3.5 \mathrm{~cm}$, with six of nine lesions being $\leq 1.0 \mathrm{~cm}$ in diameter. When treatment options were discussed, each of these patients indicated a desire to avoid scarring that results from EDC and surgical excision. Upon discussion of topical treatments, they elected treatment with ingenol mebutate because of the shorter regimen. Patients were treated from May 2014 to August 2015 at 10 to 14 days after shave biopsy confirmation of sBCC; biopsy sites were not required to be fully healed. Ingenol mebutate gel, $0.05 \%$, was applied to cover the lesion plus a $0.5 \mathrm{~cm}$ margin. Lesions were either occluded using a standard adhesive bandage (six lesions in four patients) or not occluded (three lesions in three patients). As treatment of sBCC with ingenol mebutate is off-label, these alternatives were included to observe whether occlusion had any impact on the LSRs, tolerability, or resolution of the sBCC. A $3.5 \mathrm{~cm}$ lesion (patient 4) was treated for 2 days, two lesions (patient 7) were treated for 4 days, and all other lesions were treated for 7 days. A maximum of one treatment kit with two tubes of medication was used. The variation in the number of treatment days resulted from the practical utilization of a single treatment kit that contained two tubes of ingenol mebutate gel, $0.05 \%$. The patient applied the medication once daily as instructed until the tubes were empty. We also noted whether the number of treatment days had an effect on LSR severity and tolerability.

\section{Treatment results}

All patients experienced LSRs that began on day 1 or 2 of treatment, peaked on days 2 to 7 , and largely resolved at 2 weeks (Figure 1). The most common LSRs were erythema, flaking/scaling, and crusting, which were assessed as mild. Neither occlusion nor the number of treatment days appeared to affect LSR severity. Patients reported mild itching $(n=4)$, mild burning/discomfort $(n=3)$, and 
Table I Summary of ingenol mebutate gel, $0.05 \%$, treatment of sBCC in seven patients

\begin{tabular}{|c|c|c|c|c|c|}
\hline & $\begin{array}{l}\text { Dermatologic } \\
\text { history }\end{array}$ & $\begin{array}{l}\text { sBCC } \\
\text { characteristics }\end{array}$ & Treatment course & LSRs & $\begin{array}{l}\text { Clearance } \\
\text { assessments }\end{array}$ \\
\hline $\begin{array}{l}\text { Patient I male, } \\
\text { age } 52 \text { years }\end{array}$ & None & $\begin{array}{l}\mathrm{I} .0 \mathrm{~cm}, \mathrm{R} \text { upper } \\
\text { back } \\
\mathrm{I} .5 \mathrm{~cm} \text {, middle } \\
\text { upper back }\end{array}$ & $\begin{array}{l}2 \text { sBCCs treated in June } \\
2014 \text { for } 7 \mathrm{~d} \text { with occlusion }\end{array}$ & $\begin{array}{l}\text { Mild erythema and } \\
\text { crusting } \\
\text { Mild discomfort and } \\
\text { pruritus } \\
\text { LSRs began on d } 2 \text {, } \\
\text { peaked on d } 5 \text {, and were } \\
\text { resolved at } 2 \text { wk } \\
\text { Residual erythema at } \\
2 \text { mo }\end{array}$ & $\begin{array}{l}\text { Lesions cleared at } 2 \text { wk } \\
\text { Biopsy at } 3 \text { mo } \\
\text { confirmed histologic } \\
\text { clearance } \\
\text { No recurrence at last } \\
\text { follow-up at } 4 \text { mo }\end{array}$ \\
\hline $\begin{array}{l}\text { Patient } 2 \text { female, } \\
\text { age } 47 \text { years }\end{array}$ & None & $\begin{array}{l}0.6 \mathrm{~cm}, \mathrm{~L} \text { upper } \\
\text { chest }\end{array}$ & $\begin{array}{l}\text { sBCC treated in February } \\
2015 \text { for } 7 \mathrm{~d} \text { without } \\
\text { occlusion }\end{array}$ & $\begin{array}{l}\text { Mild erythema, flaking/ } \\
\text { scaling, and crusting } \\
\text { Mild pruritus } \\
\text { LSRs began on d } 2 \text {, } \\
\text { peaked on d } 3 \text {, and were } \\
\text { resolved at } 2 \text { wk } \\
\text { LSRs treated with } \\
\text { moisturizers }\end{array}$ & $\begin{array}{l}\text { Lesion cleared at I mo } \\
\text { No recurrence at last } \\
\text { follow-up at } 2 \text { mo }\end{array}$ \\
\hline $\begin{array}{l}\text { Patient } 3 \text { male, } \\
\text { age } 58 \text { years }\end{array}$ & $\begin{array}{l}\text { Eleven sBCCs on } \\
\text { separate sites of } \\
\text { the shoulders, back, } \\
\text { and forearm from } \\
2005 \text { through } 2014 \text {; } \\
\text { all were surgically } \\
\text { treated } \\
>10 \text {-year history } \\
\text { of AK treated with } \\
\text { cryosurgery and } \\
\text { diclofenac }\end{array}$ & $\begin{array}{l}1.0 \mathrm{~cm}, \mathrm{~L} \text { anterior } \\
\text { chest }\end{array}$ & $\begin{array}{l}\text { sBCC treated in June } 2014 \\
\text { for } 7 \mathrm{~d} \text { with occlusion }\end{array}$ & $\begin{array}{l}\text { Mild erythema and } \\
\text { flaking/scaling } \\
\text { Mild burning and pruritus } \\
\text { LSRs began on } d \mathrm{I} \text {, } \\
\text { peaked on } \mathrm{d} 4 \text {, and were } \\
\text { resolved at } 2 \mathrm{wk} \\
\text { Residual erythema at } \\
2 \text { wk }\end{array}$ & $\begin{array}{l}\text { Lesion cleared at } 2 \text { wk } \\
\text { Biopsy at } 3 \text { mo } \\
\text { confirmed histologic } \\
\text { clearance } \\
\text { No recurrence at last } \\
\text { follow-up at } 14 \text { mo }\end{array}$ \\
\hline $\begin{array}{l}\text { Patient } 4 \text { male, } \\
\text { age } 65 \text { years }\end{array}$ & $\begin{array}{l}\text { 2-year history of } \\
\text { AK treated with } \\
\text { cryosurgery }\end{array}$ & $\begin{array}{l}3.5 \mathrm{~cm}, \mathrm{R} \text { anterior } \\
\text { shoulder }\end{array}$ & $\begin{array}{l}\text { sBCC treated in May } 2014 \\
\text { for } 2 \mathrm{~d} \text { without occlusion }\end{array}$ & $\begin{array}{l}\text { Mild erythema and } \\
\text { flaking/scaling } \\
\text { Mild discomfort and } \\
\text { pruritus } \\
\text { Moderate burning } \\
\text { LSRs began on d I, } \\
\text { peaked on d 2, and were } \\
\text { resolved at } 2 \text { wk } \\
\text { Mild erythema at } 3 \text { wk } \\
\text { LSRs treated with } \\
\text { moisturizers }\end{array}$ & $\begin{array}{l}\text { Lesion cleared at } 3 \text { wk } \\
\text { Biopsy at } 3 \text { mo } \\
\text { confirmed histologic } \\
\text { clearance } \\
\text { No recurrence at last } \\
\text { follow-up at } 10 \text { mo }\end{array}$ \\
\hline $\begin{array}{l}\text { Patient } 5 \text { female, } \\
\text { age } 65 \text { years }\end{array}$ & $\begin{array}{l}\text { Malignant } \\
\text { melanoma on } \mathrm{R} \\
\text { forearm; treated } \\
\text { with excision } \mathrm{AK} \text {, } \\
\text { prior treatment } \\
\text { unavailable }\end{array}$ & $\begin{array}{l}1.0 \mathrm{~cm}, \mathrm{~L} \text { posterior } \\
\text { shoulder }\end{array}$ & $\begin{array}{l}\text { sBCC treated in March } \\
2015 \text { for } 7 \mathrm{~d} \text { with occlusion }\end{array}$ & $\begin{array}{l}\text { Mild erythema, flaking/ } \\
\text { scaling, and crusting } \\
\text { LSRs began on d I, } \\
\text { peaked on d } 2 \text {, and were } \\
\text { resolved at } 2 \mathrm{wk}\end{array}$ & $\begin{array}{l}\text { Lesion cleared at } 2 \text { wk } \\
\text { No recurrence at last } \\
\text { follow-up at } 3 \text { mo }\end{array}$ \\
\hline $\begin{array}{l}\text { Patient } 6 \text { female, } \\
\text { age } 75 \text { years }\end{array}$ & None & $\begin{array}{l}1.0 \mathrm{~cm} \text {, middle } \\
\text { back }\end{array}$ & $\begin{array}{l}\text { sBCC treated in February } \\
2015 \text { for } 7 \mathrm{~d} \text { without } \\
\text { occlusion }\end{array}$ & $\begin{array}{l}\text { Mild erythema and } \\
\text { flaking/scaling } \\
\text { LSRs began on d I, } \\
\text { peaked on } \mathrm{d} 2 \text {, and were } \\
\text { resolved at } 2 \mathrm{wk}\end{array}$ & $\begin{array}{l}\text { Lesion cleared at } 2 \text { wk } \\
\text { No recurrence at last } \\
\text { follow-up at } 5 \text { mo }\end{array}$ \\
\hline $\begin{array}{l}\text { Patient } 7 \text { female, } \\
\text { age } 52 \text { years }\end{array}$ & $\begin{array}{l}\text { Nodular BCCs on } \\
\text { R arm and chest } \\
\text { treated } \\
\text { with excision in } \\
2014 \\
\text { No AK }\end{array}$ & $\begin{array}{l}\text { I.0 cm, L upper } \\
\text { back } \\
2.0 \mathrm{~cm}, \mathrm{~L} \text { lower } \\
\text { back }\end{array}$ & $\begin{array}{l}\mathrm{sBCC} \text { treated in August } \\
2015 \text { for } 4 \mathrm{~d} \text { with occlusion }\end{array}$ & $\begin{array}{l}\text { Mild erythema and } \\
\text { flaking/scaling } \\
\text { LSRs were resolved at } \\
2 \text { wk }\end{array}$ & $\begin{array}{l}\text { No recurrence at last } \\
\text { follow-up at } 4 \text { mo } \\
\text { Biopsy at } 4 \text { mo } \\
\text { confirmed histologic } \\
\text { clearance }\end{array}$ \\
\hline
\end{tabular}

Abbreviations: d, day/s; wk, weeks; mo, month/s; R, right; L, left; AK, actinic keratosis; LSRs, local skin reactions; sBCC, superficial basal cell carcinoma. 
A

\section{Before treatment}

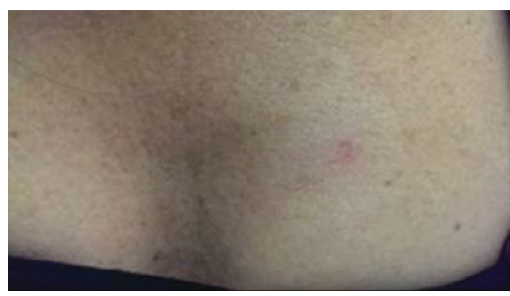

B

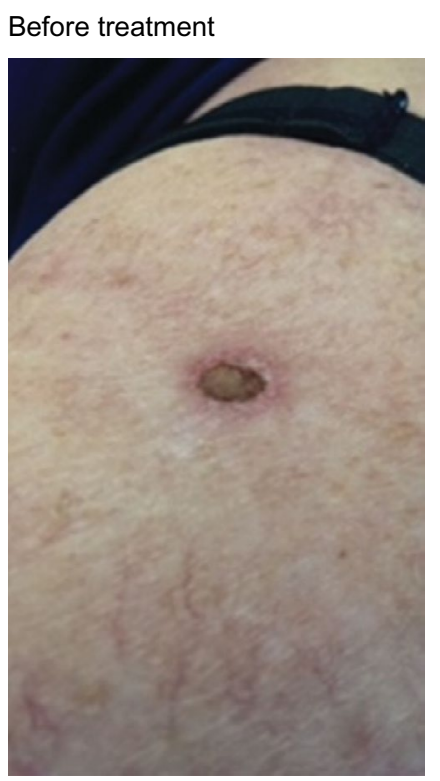

Day 10 after start of treatment

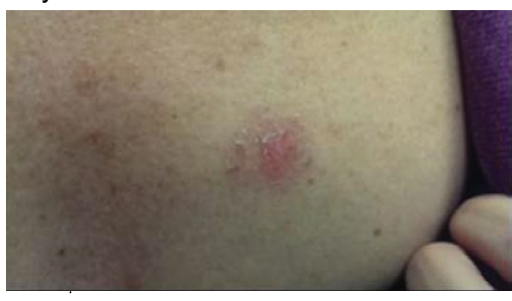

Day 12 after start of treatment

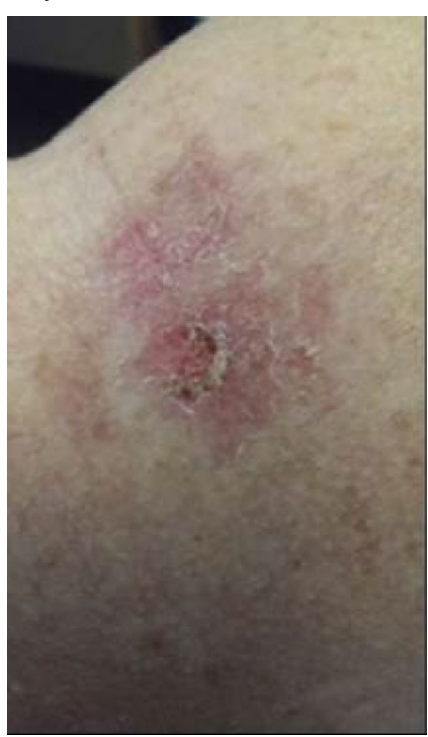

1 month after treatment

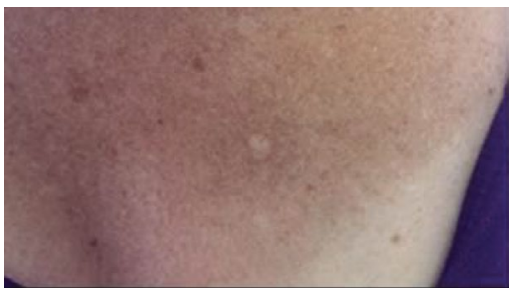

3 months after treatment

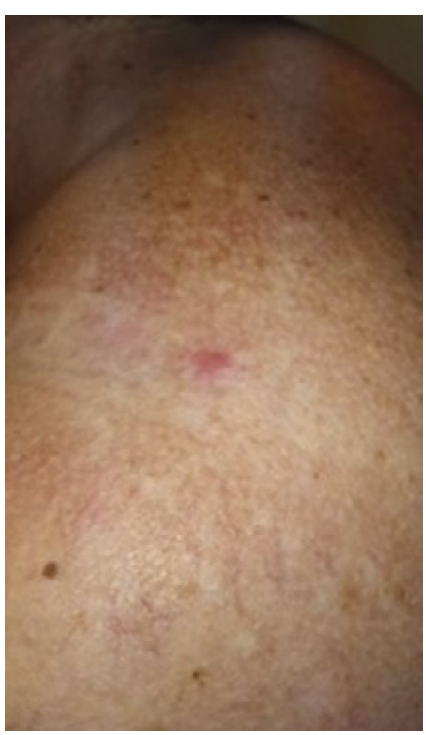

Figure I Course of treatment with 7 days of ingenol mebutate gel, $0.05 \%$.

Notes: (A) Patient 2, before treatment; the biopsy site is visible. Mild local skin reactions (LSRs) are noted at day 10 after the start of 7 days of ingenol mebutate treatment. At I month after treatment, LSRs are resolved; hypopigmentation is noted at the site of the diagnostic biopsy. (B) Patient 5 , before treatment; the incompletely healed biopsy site is visible. Mild LSRs are noted at day 12 after the start of 7 days of ingenol mebutate treatment. At 3 months after treatment, erythema is noted at the biopsy site.

moderate burning $(n=1)$. LSRs were treated in two patients with moisturizers.

All sBCCs were clinically resolved on short-term follow-up at 2 to 4 weeks. Residual mild erythema was present at 2 to 8 weeks in three patients. Repeat biopsy of six of the nine lesion sites at 3 or 4 months (in four of the seven patients) was performed and confirmed histologic clearance in all biopsy samples. None of the patients experienced scarring due to topical treatment at the treatment site. There were no clinically suspicious lesions in any patient on subsequent follow-up evaluations at 3-month intervals. The longest follow-up to date has been 14 months. All patients reported that the medicine was well tolerated.

In contrast to these seven described patients who experienced short-term clearance of sBCC after ingenol mebutate treatment, one patient in our clinic experienced clinical recurrence a few months after an $\mathrm{sBCC}$ was treated with ingenol mebutate (not occluded) and subsequently was treated with traditional surgical methods.

\section{Discussion}

$\mathrm{BCC}$ is the most common cancer in the US, and the incidence continues to rise. The goal of primary treatment is cure of the tumor, with maximal preservation of function and cosmesis. Surgical approaches offer the most effective treatment, although patients who have low-risk sBCCs may be treated with topical treatments, albeit at a lower cure rate. Nonsurgical treatments include topical treatments (fluorouracil and imiquimod), photodynamic therapy, and cryotherapy. ${ }^{13}$

The seven patients described here had histologically confirmed sBCC on the trunk. They had declined both surgical treatment and destruction with EDC, electing, instead, treatment with ingenol mebutate gel, $0.05 \%$, to minimize scarring and the total treatment time. Ingenol mebutate gel is generally administered for a few days, in contrast to topical treatments 
with fluorouracil ${ }^{14}$ or imiquimod, ${ }^{15}$ which are administered for several weeks. Although all of these agents produce LSRs, the prolonged LSRs and the adverse cosmetic effects associated with the longer treatment durations of fluorouracil and imiquimod may compromise tolerability and adherence. ${ }^{16}$

All seven patients experienced a local inflammatory response upon treatment that included erythema, flaking/ scaling, and crusting. In all patients, it was assessed as mild and generally resolved within 2 weeks. The one exception was erythema, which persisted in three patients for 2 to 8 weeks. More severe, but also self-limiting, LSRs were described in a case report of 2-day treatment with ingenol mebutate gel, $0.05 \%$, for a $4 \mathrm{~cm} \mathrm{sBCC}$ on the back. ${ }^{17}$

None of our seven patients had scarring, beyond that from the shave biopsy, which could be assessed as related to topical treatment. However, scarring at 3-month follow-up has been reported in a patient who was treated for superficial and micronodular BCC with ingenol mebutate gel, 0.05\%, beginning at 1 day after curettage of the lesion. ${ }^{18}$

The findings from our case studies indicate that ingenol mebutate gel, $0.05 \%$, was well tolerated for the treatment of biopsy-confirmed sBCC on the trunk. All patients experienced short-term clinical remission and continue to be monitored for recurrence at 3-month intervals.

\section{Limitations}

This is a small case series of seven patients in a community dermatology setting who were assessed over a relatively short-term follow-up. Confirmation of the safety and efficacy of ingenol mebutate for the treatment of $\mathrm{sBCC}$ requires evaluation in a larger number of patients and evaluation of recurrence rates from studies with at least 5 years follow-up, in order for the recurrence rates to be considered valid. ${ }^{7}$ Further, while it was appropriate to consider ingenol mebutate gel, $0.05 \%$, for these patients, all patients should be individually evaluated to determine the most appropriate treatment for their particular sBCC.

\section{Acknowledgment}

Editorial support was provided by Tanya MacNeil, $\mathrm{PhD}$, from $p$-value communications, and funded by LEO Pharma Inc.

\section{Disclosure}

The author reports no conflicts of interest in this work.

\section{References}

1. Wu X, Elkin EE, Marghoob AA. Burden of basal cell carcinoma in USA. Future Oncol. 2015;11:2967-2974.

2. Rogers HW, Weinstock MC, Harris AR, et al. Incidence estimate of nonmelanoma skin cancer in the United States, 2006. Arch Dermatol. 2010;146:283-287.

3. Rogers HW, Weinstock MA, Feldman SR, Coldiron BM. Incidence estimate of nonmelanoma skin cancer (keratinocyte carcinomas) in the U.S. population, 2012. JAMA Dermatol. 2015;151:1081-1086.

4. Wu S, Han J, Li WQ, Li T, Qureshi AA. Basal-cell carcinoma incidence and associated risk factors in U.S. women and men. Am J Epidemiol. 2013;178:890-897.

5. Christenson LJ, Borrowman TA, Vachon CM, et al. Incidence of basal cell and squamous cell carcinoma in a population younger than 40 years. JAMA. 2005;294:681-690.

6. Ferrucci LM, Cartmel B, Molinaro AM, et al. Indoor tanning and risk of early-onset basal cell carcinoma. J Am Acad Dermatol. 2012; 67:552-562.

7. Kauvar AN, Cronin T, Roenigk R, et al. Consensus for nonmelanoma skin cancer treatment: basal cell carcinoma including a cost analysis of treatment methods. Dermatol Surg. 2015;41:550-571.

8. Madan V, Lear JT, Szeimies RM. Non-melanoma skin cancer. Lancet. 2010;375:673-685.

9. Chren MM, Linos E, Torres JS, et al. Tumor recurrence 5 years after treatment of cutaneous basal cell carcinoma and squamous cell carcinoma. J Invest Dermatol. 2013;133:1188-1196.

10. Clark CM, Furniss M, Mackay-Wiggan JM. Basal cell carcinoma: an evidence-based treatment update. Am J Clin Dermatol. 2014;15: $197-216$.

11. Picato (ingenol mebutate) gel $0.015 \%, 0.05 \%$ [package insert]. Parsippany, NJ: LEO Pharma Inc; 2015.

12. Siller G, Rosen R, Freeman M, et al. PEP005 (ingenol mebutate) gel for the topical treatment of superficial basal cell carcinoma: results of a randomized phase IIa trial. Australas J Dermatol. 2010;51: 99-105.

13. National Comprehensive Cancer Network. Basal cell skin cancer, version 1. 2016. Available from: http://www.nccn.org/professionals/ physician_gls/pdf/nmsc.pdf. Accessed February 24, 2016.

14. Efudex (fluorouracil) cream 5\% [package insert]. Bridgewater, NJ: Valeant Pharmaceuticals North America LLC; 2016.

15. Aldara (imiquimod) cream, $5 \%$ [package insert]. Bridgewater, $\mathrm{NJ}$ : Valeant Pharmaceuticals North America LLC; 2014.

16. Love WE, Bernhard JD, Bordeaux JS. Topical imiquimod or fluorouracil therapy for basal and squamous cell carcinoma: a systematic review. Arch Dermatol. 2009;145:1431-1438.

17. Cantisani C, Paolino G, Cantoresi F, et al. Superficial basal cell carcinoma successfully treated with ingenol mebutate gel $0.05 \%$.DermatolTher. 2014; 27:352-354.

18. Nguyen NM, Tremaine AM, Zachary CB. A scarring reaction to the treatment of basal cell carcinoma with ingenol mebutate. Skinmed. 2014; 12:317-318.
Clinical, Cosmetic and Investigational Dermatology

Publish your work in this journal

Clinical, Cosmetic and Investigational Dermatology is an international, peer-reviewed, open access, online journal that focuses on the latest clinical and experimental research in all aspects of skin disease and cosmetic interventions. This journal is included on PubMed. The manuscript management system is completely online

\section{Dovepress}

and includes a very quick and fair peer-review system, which is all easy to use. Visit http://www.dovepress.com/testimonials.php to read real quotes from published authors 